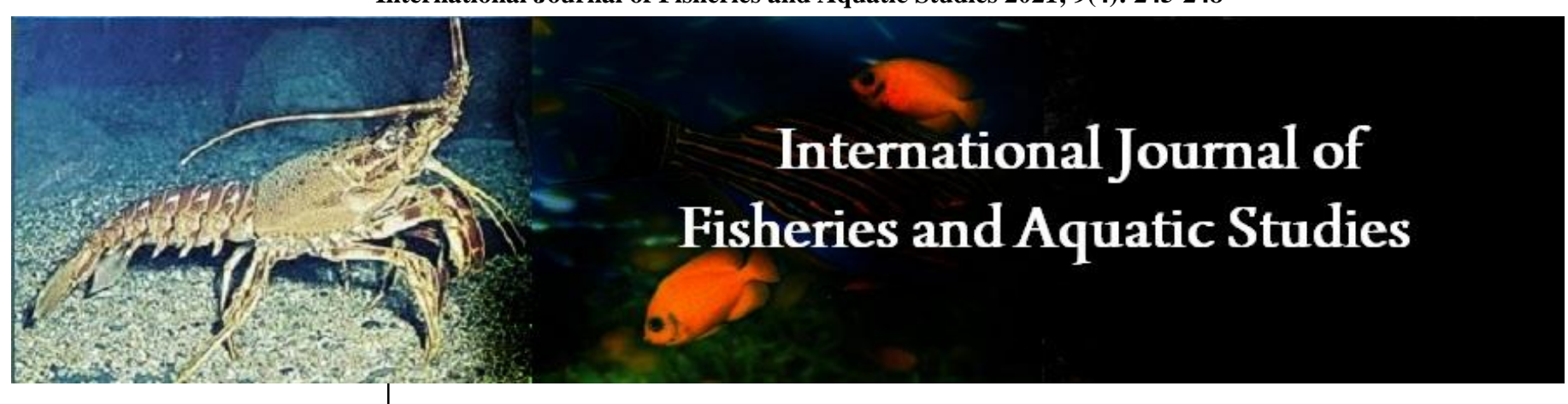

E-ISSN: 2347-5129

P-ISSN: 2394-0506

(ICV-Poland) Impact Value: 5.62

(GIF) Impact Factor: 0.549

IJFAS 2021; 9(4): 245-248

(C) 2021 IJFAS

www.fisheriesjournal.com

Received: 25-05-2021

Accepted: 27-06-2021

\section{Hasi Suprapto}

Professor, Department of

Fishery and Aquaculture,

Airlangga University, Surabaya,

Indonesia

\section{Sudarno}

Department of Fishery and

Aquaculture, Airlangga

University, Surabaya, Indonesia
Corresponding Author:

Hasi Suprapto

Professor, Department of

Fishery and Aquaculture,

Airlangga University, Surabaya,

Indonesia

\section{Increased survival rate of hybrid grouper Epinephelus $s p$. after feeding with microalginate particles}

\section{Hasi Suprapto and Sudarno}

DOI: https://doi.org/10.22271/fish.2021.v9.i4c.2543

\begin{abstract}
This research aims to increase fish survival rate by providing oral feed containing formalin killed cells of Vibrio alginolyticus. It investigates whether it is effective or not. In the hatchery, the survival rate of grouper Epinephelus $s p$. is only 2-3 percent. The death of 4-6 g size grouper infected by Vibrio sp. is very quick. Fish dies only after $12 \mathrm{~h}$ of infection. The problem on larval stage is that the fish size is small. So, it is not possible to perform injection or immersion because it may result in high stress of the fish. The only way to overcome the problem is oral provision by incorporation of feed. Formalin-killed cells of Vibrio were coated with alginate and administered orally through feed. Alginate microparticles were prepared from colloidal complexes using sodium alginate gel as a core. All alginate solutions $(2 \% \mathrm{w} / \mathrm{v})$ were prepared by dissolving sodium alginate in deionized water. The survival rate of fish increased to 20-22 percent; the antibody titer was 64-256 and phagocytic rate was 32-60. The increased survival rate was due to higher antibody and superoxide production in fish. This study suggests that vaccination for small fish can be done in the future by making various improvements.
\end{abstract}

Keywords: Epinephelus sp., microalginate particles, phagocytic rate, grouper, larvae

\section{Introduction}

Indonesian grouper export in 2016 was quite large. Central Bureau of Statistics (BPS) noted that in 2016 Indonesia exported groupers to various countries with the value which reached 32.18 million US dollars or about IDR 427 billion.

However, the survival rate of grouper seeds Epinephelus sp. is only 2-3 percent after hatch. The death of 4-6 g-sized grouper seeds infected by Vibrio sp. occurs quickly ${ }^{[9]}$, no more than 12 hours after infection. The mortality rate may reach 80 percent of the population. There are two types of Vibrio bacteria that infect the grouper, V. alginolyticus and V. anguillarum [9], while those infecting shrimp are Vibrio harveyi and Vibrio splendidus ${ }^{[14]}$, similar to those identified in the Philippines [6]. In Malaysia, Vibriosis is caused by bacteria and $V$. parahaemolyticus as well as $V$. alginolyticus. Whereas, in Japan, Vibrio $s p$. P. japonicus reportedly attacked shrimp ${ }^{[15]}$. Vibriosis found in China was mainly caused by $V$. parahaemolyticus in shrimp larvae ${ }^{[8]}$. Mass mortalities on larval stage is due to the small size of the fish. So, it is not possible to carry out injection or immersion because it may result in high stress on the fish.

There is one possible way to overcome the infection, that is by incorporating Vibrio antigen into the feed. Vaccination can enhance specific and non-specific self-defense mechanisms. Specific defense can be enhanced by incorporating Vitamic $C$ into feed ${ }^{[7]}$. This study aims to determine whether the incorporation of Vibrio antigen into the feed can enhance the survival rate of grouper larvae.

This study reveals that increasing the survival rate of small grouper fish can possibly be done by feeding the fish with alginate particles containing formalin killed cells of Vibrio alginolyticus. This study helps the researchers uncover critical areas of vaccination that many researchers were unable to explore. Thus, a new theory on little fish vaccination may be invented. 


\section{Materials and Methods \\ Bacteria strain}

Vibrio parahaemolyticus was grown on cellophane-covered NA for 24-48 hours ${ }^{[17]}$. Then, they were harvested and placed into a Petri dish. The bacteria were added with $2 \mathrm{ml}$ of phosphate buffered saline (PBS), and washed 3 times for 10 minutes. The bacteria were killed with $3 \%$ formalin for 72 hours. Each FKC obtained was washed 3 times for 10 minutes by centrifugation. Bacterial density was made $50 \mathrm{mg} / \mathrm{ml}$. It was then stored in $-4{ }^{\circ} \mathrm{C}$ and dialyzed with PBS.

\section{Preparation for alginate}

Alginate microparticles were prepared from colloidal complexes using sodium alginate gel as a core. All alginate solutions $(2 \% \mathrm{w} / \mathrm{v})$ were prepared by dissolving sodium alginate in deionized water. Micronized prednisolone powder $(2-4 \% \mathrm{w} / \mathrm{v})$ plus Vibrio antigen was then dissolved in sodium alginate and stirred for $10 \mathrm{~min}$, and sprayed directly on the solution of calcium chloride $(0.5-1.0 \% \mathrm{w} / \mathrm{v})$ containing $0.5-$ $1.5 \%$ chitosan. Microparticles were left for 2 hours to harden before being washed $2 \mathrm{x}$ with DW at room temperature.

\section{Fish used in this study}

Twenty fish (7 $\mathrm{cm}$ in length) in each aquarium were fed at libitum for 7 days. Fish that had been feed, were challenged with Vibrio alginolyticus at a dose of 7.1 x 104 CFU. The fish were kept in an aquarium for 14 days and their mortality rates were recorded.

\section{Feeding fish with alginate}

Another group of grouper of $\pm 10 \mathrm{~cm}$ in length was injected intraperitoneally with 0.01 of glycogen to stimulate macrophage production. After 24 hours, the fish were anesthetized with MS-222. Blood was taken from the base of the tail to prevent the contamination of macrophage with red blood. A half milliliter of Leibovitz medium (L-15) containing 2\% Fetal Bovine Serum (FBS) and 10 units $/ \mathrm{ml}$ heparin was injected intraperitoneally into the grouper. The rest of the macrophage was washed again with $0.5 \mathrm{ml}$ of L-15. Macrophage cells were then centrifuged at 400xg for 10 minutes and dissolved in L-15. Viable cells (living cells) were observed and counted by trypan blue staining. The cell density was calculated $2-5 \times 10^{6}$ cells/ml using $\mathrm{H}$ aemocytometer (Assistant, Karl Hecht KG Germany).

\section{Phagocytosis}

Bacteria and macrophages (vaccinated and control) were mixed and incubated at $25^{\circ} \mathrm{C}$ for 30 mins by shaking at 25 rpm, allowing contact between the macrophages and the bacteria. The macrophage was taken to be smeared on a slide glass that had been coated with albumin and stained with May-Grunwald Giemsa. Further, phagocytosis was calculated.

\section{Intracellular $\mathrm{O2}$}

Head kidney macrophages that have been collected were poured into L15 medium (Sigma, USA). The macrophages were then filtered with $100 \mu \mathrm{m}$ nylon. Percoll ( $2 \mathrm{ml}$ of $30-$ $51 \%$, Sigma, USA) was added to the cell suspension and centrifuged at $400 \mathrm{xg}$ for $40 \mathrm{~min}$ at $4^{\circ} \mathrm{C}$. Macrophages obtained were poured into the L-15 (10\% fetal bovine serum) at concentration of $1 \times 10^{7}$ cells $/ \mathrm{ml}$. Macrophage was then adjusted to $1 \times 10^{6}$ cells $/ \mathrm{ml}$ and poured into the wells. Superoxide anion production was conducted by nitroblue tetrazolium (NBT) ${ }^{[11]}$. NBT solution per well $(100 \mathrm{ml}, 1 \mathrm{mg}$ of NBT and $1 \mathrm{mg}$ phorbol 12-myristate 13 acetate in $1 \mathrm{ml}$ of medium L-15) was added to the wells and incubated at $30^{\circ} \mathrm{C}$ for 1 hour. Cells were fixed with $100 \%$ alcohol and then 120 $\mathrm{ml}$ of $\mathrm{KOH}(2 \mathrm{M})$ and $140 \mathrm{ml}$ dimethyl sulfoxide was added to the formation of formazan. Superoxide anion production was measured at OD $620 \mathrm{~nm}$.

\section{Results and Discussion}

After fish were fed a diet containing whole cell bacteria (whole cell vaccine) the phagocyte rate was between $34-53$ and control 32 percent, while the survival rate (SR) was 20-22 and 52 control percent, this indicates an increase in life, because it usually does not up to 5 percent (normally 2-3 percent). This increase was related due to an increase in phagocytosis and antibody production (Table 1) and an increase in intracellular $\mathrm{O} 2$ production (Figure 3), both of which increased significantly, this in turn would lead to an increase in the grouper survival rate. Phagocytosis is the process by which cells engulf some solid particles to form internal vesicles known as phagosomes. Phagocytosis is, in fact, a specific form of endocytosis involving vesicular interiorization of particles. Degradation may be oxygendependent or oxygen-independent. Oxygen-dependent degradation depends on NADPH and the production of reactive oxygen species. Hydrogen peroxide and myeloperoxidase activate a halogenating system, which leads to the creation of hypochlorite and the destruction of bacteria [3].

Table 1: Survival rate, phagocytic rate and antibody titer of vaccinated fish

\begin{tabular}{|c|c|c|c|}
\hline Doses at libitum & Survival Rate (\%) & Antibody titer & Phagocytosis Rate (PI) \\
\hline Replication 1 & 20 & 64 & 34 \\
\hline Replication 2 & 20 & 128 & 53 \\
\hline Replication 3 & 22 & 256 & 52 \\
\hline Control & 52 & 16 & 32 \\
\hline
\end{tabular}




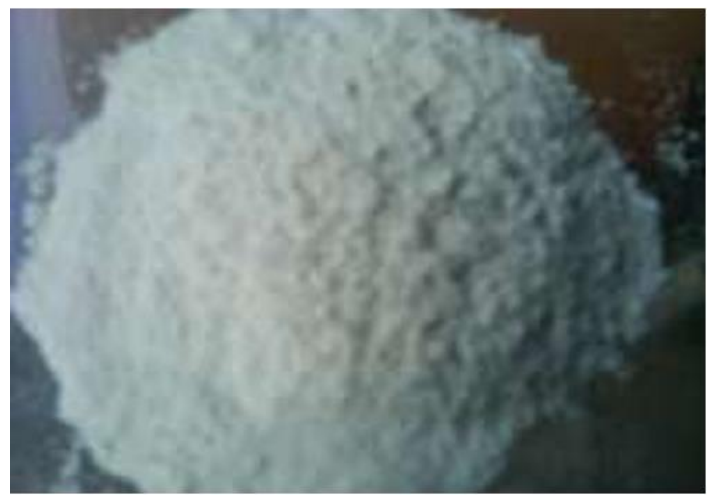

Fig 1: Alginate vaccine powder

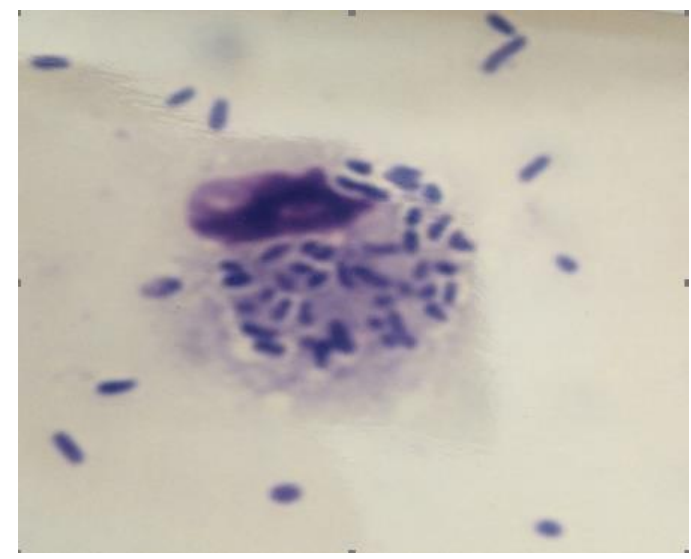

Fig 2: Macrophage ingested bacteria cells

The antibody titer detects the presence and measures the amount of antibodies in fish blood. The amount and diversity of antibodies correlate with the strength of body's immune response. Superoxide dismutase is an important antioxidant defense in nearly all living cells exposed to oxygen. One exception is Lactobacillus plantarum and related lactobacilli, which use a different mechanism to prevent damage from reactive (O2-).

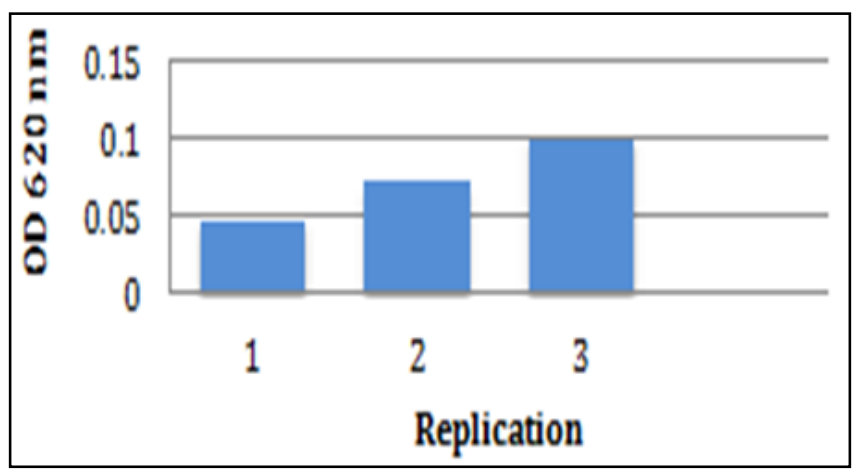

Fig 3: Production of inracelluar $\mathrm{O} 2$ by macrophage

Protection of vaccinated fish is produced from a high antigen concentration, but if the antigen level is too high, sometimes it does not confer proper protection. Optimum concentration between the highest and lowest dose and the same pattern will be followed by an increased antibody titer, which indicates a high degree of protection as well. Production of superoxide anion in the immune system is critical to the animal itself as a defense system against disease and significant as an immune function (Secombes, 1996; Crosby et al., 2010) [12, 1]. Superoxide anion production varies between fish because the production of superoxide anion in this study tended to increase (Fig 3).

Vaccines are small amounts of microbes (killed or attenuated) or antigens administered to stimulate the immune system to produce memory cells against a specific disease. Protection of grouper varies and depends on the dose used. Memory cells are so effective that fish's immune system may fight off an infection before any symptoms occur. The main obstacle of oral feeding may be "bad taste" or the palatability of feed. The fish were fed twice a day and left hungry. It would increase the appetite of fish. Palatability has been a problem of using oral system. Antigens that have a Molecular Weight (MW) more than $5 \mathrm{kD}$ are immunogenic, whereas antigens with smaller molecular weight are not. It is known that fish only have IgM, the main immunoglobulin specific against bacterial infection. However, this immunoglobulin affinity is very low. Antigens from whole bacteria provide good protection results. In this study, the mortality of control fish was 52 percent, because they only received Phosphate Buffered Saline, $\mathrm{pH} 7.0$ (PBS) alone. The survival rate of vaccinated fish is between 20-22 percent. The potential immunogen is in the cell walls of the bacteria because most of the experimental vaccination with whole bacterial cells provides good protection. Vaccination with a low antigen concentration did not result in protection. The protection of vaccinated fish is produced from a high concentration of antigen. However, if the antigen level is too high, sometimes it does not confer good protection. An optimal concentration between the highest and lowest dose and the same pattern will be followed by an increased antibody titer which indicates a high degree of protection as well. Basically, protective antigen level is above $5 \mathrm{kD}$ to 200 $\mathrm{kD}^{[4]}$.

The result of tested grouper is presented in Table 1. Formalinkilled cells antigen provides protection against Vibrio challenged. Protection due to the large size and intact antigen has not been broken or damaged due to physical or chemical factors. Antibody production is dependent upon the age of the fish, e.g. trout after 4 weeks of age, but memory development takes at least 8 weeks.

An antigen that has a lower MW could not be recognized by lymphocytes of fish. There are no scientific explanations for this. Production of superoxide anion in the immune system is critical to the animal itself as a defense system against diseases and significant as immune function ${ }^{[1,11]}$. Superoxide anion production varies between the fish because the production of superoxide anion tends to increase in this study (Fig 3). Superoxide dismutase is an enzyme that alternately catalyzes the dismutation of the superoxide (O2-) radical into either ordinary molecular oxygen $(\mathrm{O} 2)$ or hydrogen peroxide $(\mathrm{H} 2 \mathrm{O} 2)^{[17]}$. Superoxide is produced as a by-product of oxygen metabolism and, if not regulated, causes many types of cell damage ${ }^{[2]}$. Hydrogen peroxide is also damaging and is degraded by other enzymes, such as catalase. Thus, SOD is an important antioxidant defense in nearly all living cells exposed to oxygen. One exception is Lactobacillus plantarum and related lactobacilli, which use a different mechanism to prevent damage from reactive $(\mathrm{O} 2-)^{[17]}$.

Similarly, phagocytic rate (PR) increased after vaccination. This process is actually easy to understand because, when compared to controls, it varied enormously and this phenomenon occurred almost in every vaccination. Although this study has not obtained excellent results, at least, it has given a hope that the vaccination of small fish is possible in the future. The success of vaccination is expected to increase grouper production and reduce the poverty of fishermen. 
As conclution, the survival rate of fish increased to $20-22$ percent; antibody titer was 64-256 and phagocytic rate was 32-60. The increase of survival rate was due to higher antibody and superoxide production in fish. This study gives a hope that vaccination for small fish can be done in the future by making various improvements.

\section{Acknowledgement}

This research was funded by the Ministry of Research and Higher Education, the Republic of Indonesia with Contract Number: 854 / UN3 / 2018

\section{Conflict of interest}

We certify that there is no conflict of interest with any financial organization regarding the material discussed in the manuscript.

\section{References}

1. Crosby CT, Petty BD, Hamlin HJ, Guillette Jr LJ, Hill JE, Hartmann KH et al. Plasma cortisol, blood glucose, and marketability of koi transported with the Metomidate hydrochloride. North Amer. J. Aqua 2010;72:141-149.

2. Hatting J. Blood sugar as indicator of sress in the fresh water fish, Laneo capensis (Smith). J. Fish Biol 1976;10:191-195.

3. Egidius E, Anderson K. Bath immunization-a practical and non stressing method of vaccinating farmed sea rainbow trout Salmo gairdneri Richardson against Vibriosis, J. Fish. Dis 1979;2:405-410.

4. Ellis AE. Fish Vaccination. Academic. Press 1989,1-50p.

5. Joice JE. Effect of sublethal dissolved oxygen stress on bloog glucose and susceptibility of Streptococcus agalactiae in Nile Tilapia Oreochromis niloticus. J Aquatic Anim Heatlh 2003;15:202-208.

6. Lavilla-Pitogo CR, Baticados MCL, Crus-Lazierda ER, dela Pena LD. Occurrence of luminous bacterial disease of Penaeus monodon larvae in the Philliphines. Aquaculture 1990;91:1-13.

7. Li Y, Lovell RT. Elevated level of dietary ascorbic acid increased immune responses in chanel catfish. J. Nutrition 1985;115:123-131.

8. Marcel Martínez-Porchas, Luis Rafael Martínez-Córdov, Rogelio Ramos-Enriquez. 2000 Pan-American Journal of Aquatic Sciences 2009;4(2):158-178

9. Meng QX, Yu KK. Diseases of penaeid shrimp in larval rearing period. Mar. Fish 1982;4:10-15

10. Murjani M. El maut itu bernama Vibrosis. (The death caused by Vibrio, in Indonesian). Trubus 2004;35:118119.

11. Remya V, Philip B. Antioxidant responses and lipid peroxidation in Mozambique tilapia (Oreochromis mossambicus) exposed to phenol and m-cresol. Indian J. Fish 2016;63(2):86-92.

12. Secombes CJ, Chung S, Jeffries AH. Superoxide anion production by rainbow trout macrophages detected by the reduction of ferricytochrome C. Dev. Comp. Immunol 1988;12:201-206.

13. Secombes CJ. The non-specific immune system: Cellular defences. Edited by Iwama, G and Nakanishi, T: In the fish immune system: Organism, pathogens and environment. Academic Press. UK 1996,63-105p.

14. Song YL, Hsieh YT. Immunostimulan of tiger shrimp Penaeus monodon macrophage for generation of microbial substances: Analysis of reactive oxygen species. Develop and Comp Immunol 1994;18:201-209.

15. Sunaryanto A, Mariam A. Occurrence of a pathogenic bacteria causing luminescence in penaeid larvae in Indonesia hatheries. Bull. Brackishwater. Aqua. Devl. Center 1986;8:64-70

16. Takahashi Y, Itami T, Maeda M, Kondo M. Bacterial and viral disease of kuruma shrimp Penaeus japonicus in Japan. Fish Pathol 1998;33:357-365.

17. Wedemeyer GA. Physiology of fish in intensiveculture systems. Chapman and Hall, New York 1996.

18. Suprapto H, Hara T, Nakai T, Kiyokuni Muroga. Purification of a lethal toxin of Edwardsiella tarda. Fish Pathology 1996;31(4):203-207.

19. Vanaporn M, Wand M, Michell SL, Sarkar-Tyson M, Ireland P, Goldman S et al. "Superoxide dismutase $\mathrm{C}$ is required for intracellular survival and virulence of Burkholderia pseudomallei". Microbiology 2011;157:2392-400. 